\title{
MEANING OF WORK FOR MANAGERS IN THE BRAZILIAN CONTEMPORARY BUSINESS CONTEXT
}

\author{
ELIANE M. P. G. BIANCHI \\ (iD) https://orcid.org/0000-0002-2622-2459
}

To cite this paper: Bianchi, E. M. P. G. (2018). Meaning of work for managers in the Brazilian contemporary business context. Revista de Administração Mackenzie, 19(5). doi:10.1590/1678-6971/ eRAMG180046

Submission: Apr. 13, 2018. Acceptance: May 28, 2018.

Centro Universitário Campo Limpo Paulista (Unifaccamp), Campo Limpo Paulista, SP, Brazil.

\footnotetext{
(c)) BY 


\section{ABSTRACT}

Purpose: To examine how professionals in managerial positions in Brazil define the meaning of work and thereby initiate a reflection on organizational implications and consequences.

Originality/value: This study addresses two research opportunities. It develops the thematic meaning of work beyond professional categories, emphasizing organizational and management positions and approaches in a complementary way, the research on managers that focuses primarily on personal development and execution of the organizational role.

Design/methodology/approach: The research approach uses mixed methods-both qualitative and quantitative methods (interview, questionnaire, and focus group). Across all phases, 316 managers and executives participated in the research. Variables of the Meaning of Work (MOW) model supported the data collection. Descriptive and inferential statistics and multivariate data analysis were used for data treatment.

Findings: Although recognized as a pleasant, paid activity of high centrality in life, fulfilling intrinsic values (recognition, autonomy, learning opportunities), work has different interpretations based on where it is executed, whom it benefits, extrinsic values expectations, and ability to handle stress factors. Different from other international studies, this work has found possible relationships between the meaning of work and organizational culture. The meaning of the work of managers has organizational implications by impacting daily work, managerial styles, and the implementation of people management practices.

\section{KEYWORDS}

Meaning. Meaning of work. Managers. Organizations. Meaning of work for managers. 


\section{INTRODUCTION}

Meaning, meaning of work, purpose, connection, engagement, recognition, commitment, respect and involvement. Unfortunately, these are topics that are often discussed from a negative perspective and that have been largely absent in surveys on human behavior in the workplace over the last 10 years (Crabtree, 2013; Society for Human Resource Management [SHRM], 2017; Ulrich \& Ulrich, 2011).

Because of changes occurring in different variables in the competitive scenario, the relationships between professionals and organizations also experience relevant changes. External competitive demands require new management efforts to increase efficiency, productivity (Markos \& Sridevi, 2010), and flexibility (Society for Human Resource Management [SHRM], 2012; Trindade, Trindade, \& Nogueira, 2015). Technology's rapid evolution has changed the workplace and the way work is performed (Markos \& Sridevi, 2010; PricewaterhouseCoopers [PwC], 2018). As part of this complexity, demographic and social trends have changed the businesses workforce reinforcing diversity and multigenerational workers (PwC, 2018).

In addition to being responsible for the internalization of changes (Markos \& Sridevi, 2010), business managers act as the liaison between company and employee to ensure employees' engagement and alignment (Fernandes, Siqueira, \& Vieira, 2014; Yukl, 2012), which results in meaningful work. To better execute his/her mission/duty, the managers must also find meaning in his/her own work. In fact, the consequences of modernity, like sense of loss of control and endless individual development, increase the need for immediate gratification and individualism (Bauman, 2000). This permeates organizational relationships regardless the complexity of the role performed and may affect the interpretation of the work.

Due to this context, the purpose of this research is to examine how professionals in managerial positions in Brazil define the meaning of work and thereby initiate a reflection on organizational implications and consequences.

This study addresses two research opportunities. It develops the thematic meaning of work beyond professional categories, emphasizing organizational positions (Silva \& Simões, 2015) and approaches, in a complementary way, the research on managers today focused primarily on personal development and the execution of organizational roles (Bianchi, Quishida, \& Foroni, 2017; Spisak, O’Brien, Ncholson, \& Van Vugt, 2015). 


\section{MEANING OF WORK}

Reflections on the meaning of work must consider work evolution and the historical context. One's reasons for working and expectations from it is an individual reference that affects and is shaped by the organizational environment.

\subsection{Brief retrospective on the evolution of work}

The origin of the word work is controversial and transits among positive and negative meanings throughout history (Amaral, 2008; Bertoncelo \& Junqueira, 2018; Dourado, Holanda, Silva, \& Bispo, 2009). Currently, work has multiple meanings and some orientations. Considered a job means the exchange contract between parties specifying what to do and the agreed compensation or, also, an individual occupation with a set of compensated activities in an organized economic system (Morin, 2008). Considered a career is the sequence of experiences an individual has throughout life (Arthur \& Rousseau, 1996; Hall, 1976) that can bring an increase in salary, prestige, and social status (Martin, 2010). As call, is a vocation one pursues out of passion and/or a desire to benefit society (Dik et al., 2014, Martin, 2010; Rosso, Dekas, \& Wrzesniewski, 2010).

When analyzing different philosophical and sociological perspectives, classical thinkers define work positively but in different ways, according to his/her time in history (Amaral, 2008; Bertoncelo \& Junqueira, 2018). Aristotle understood work as intellectual and moral virtues (Amaral, 2008). According to these virtues, a good person lives a fully realized life, performing a set of actions with a meaning greater than the acts themselves. Therefore, the work is a way for achieving one's full potential (eudemonia). Max Weber conceptualized work as a vocation related to the search for truth and knowledge (Amaral, 2008). Labor became an important and critical act and way of moral self-realization and fulfillment of duty (Heller \& Ruiz-Quintanilla, 1995).

Besides definitions, work can be analyzed throughout the world history. In the Classical conception, Greek-Roman societies, work was torture. Connected to basic needs, work was executed by poor people and slaves, not dignifying freedom or grandeur of the man (Bertoncelo \& Junqueira, 2018; Oliveira, Piccinini, Fontoura, \& Schweig, 2004). During medieval times, the feudal system also brought a negative conception of work. The servants lived 
in a system of domination, with their lives almost exclusively dedicated to the land. The work provided the subsistence of the parties (servants and lords).

At the end of the Middle Ages and during the Renaissance, the Protestant Reformation incorporated the vision of profit and wealth (Cortella, 2007; Dourado et al., 2009), and work became a physical and intellectual effort that would lead to a result (Oliveira et al., 2004, Rohm \& Lopes, 2015). In the Modern Age, with industrialization and capitalism, work gained the conception of value creation and wealth, transformation of humanity, elimination of poverty, prosperity and consumption (Araújo \& Sachuck, 2007; Bertoncelo \& Junqueira, 2018; Cortella, 2007; Dourado et al., 2009; Gorz, 2007; Oliveira et al., 2004). The free salaried worker appeared. Both Aristotle's vision of virtue and Weber's vision of vocation remained, and work became a way for man to command his destiny (Bauman, 2000).

However, the conception of work in the Modern Age also has negative aspects. Both management methodologies and practices that seek to maximize efficiency and productivity and the complexity of the current competitive scenario have consequences for professionals (Bertoncelo \& Junqueira, 2018, Rohm \& Lopes, 2015). The establishment of routines, the fragmentation of activities, the excess of work, project-based approaches, and the excessive use of social networking may have consequences such as alienation, depersonalization, and even unemployment (Antunes, 2009; Morin, 2001; Rohm \& Lopes, 2015).

Reflecting on the future of work, despite the increase in project management and the use of virtual networks and communities (Araújo \& Sachuck, 2007), organizational movements reinforce decentralization. In turn, this will reflect on more specialization, economy of scale, and communication cost reduction (Malone, 2004; Rohm \& Lopes, 2015). This movement may represent a series of positive aspects such as greater employee participation and capacity of adding knowledge, but may also result in more conflicts and greater complexity of work positions, resulting in new relationships/contracts between organizations and individuals.

When one analyzes the evolution of work from an ideological perspective, from burden to vocation, work became an end itself, responsible for the technical progress of humanity (Dourado et al., 2009). From an economic perspective, work acquired a central positive position in human life (Bianchi, 2013), and from a psychological perspective, work is today a fundamental reference for the individual, contributing to the construction of self-image and identity, a way of social insertion. Work includes mental, emotional, and physical worlds, strengthening feelings of satisfaction, self-realization, 
and belonging of individuals, bringing meaning to life (Bauman, 2004; Dourado et al., 2009). The process of executing work may also bring pleasure (Morin \& Aubé, 2008).

\subsection{Understanding meaning of work}

The search for meaning is the first motivator in life, vital for the human being (Frankl, 2008). This meaning must be acceptable for an individual and for the society in which he/she is inserted (Wrzesniewski, 2003).

Many of the international studies on the meaning of work use the words meaning or meaningfulness indifferently, although the words are related to the type of meaning and quantity of meaning, respectively (Rosso et al., 2010). In studies conducted in Brazil, the words meaning and significance are also used indifferently. Andrade, Tolfo, and Dellagnello (2012) argue that significance would be collectively developed in a certain historic, economic, and social context, represented by instruments, techniques, and language, while meaning is a personal production, a response of the individual apprehension to the collective significances.

The meaning of work is a positive representation of the act of working, developed through perception and reproduction of meaning, where the situations experienced in the work environment are appreciated and representative for someone (Bianchi, 2013, Boas \& Morin, 2017; Tolfo, 2015, Wrzesniewski, 2003). The absence of meaning in work, whether in the process or whether in the result, may lead the individual to alienation (Morin, 2004) and to the diminishment of the capacity of thinking and acting.

Andrade et al. (2012) differentiate the instrumental meaning of work (survival, financial return, and safety) from the substantive meaning of work (autonomy, relationships, learning, development, acknowledgment), founding their arguments on the concept of instrumental and substantive rationality, both always present in people (Silva \& Simões, 2015).

\subsection{Meaning of work theoretical models}

Theoretical models also conceptually deepen a construct and systematize the empirical research process. Despite the meaning of work being an individual representation, the existence of models reflects the possibility of shared interpretations of expectations on work on the organizational and social dimensions (Morin, Tonelli, \& Pliopas, 2007; Ruiz-Quintanilla \& Claes, 2000). 
This study revises four models that frame the meaning of work: the model of components of meaning (Morin, 2004, 2008; Morin \& Aubé, 2008); the model of characteristics of employment (Hackman \& Oldham, 1976); the model of significant work environment (Chalofsky, 2010), and the Meaning of Work (MOW) dimensions model (Ruiz-Quintanilla \& Claes, 2000). Figure 2.3.1 shows a comparison of the models.

\section{(Figure 2.3.1)}

SYNTHESIS OF MEANING OF WORK MODELS

\begin{tabular}{|c|c|c|c|c|}
\hline & $\begin{array}{c}\text { Morin } \\
\text { components }\end{array}$ & $\begin{array}{c}\text { Hackman \& } \\
\text { Oldham } \\
\text { work design }\end{array}$ & $\begin{array}{l}\text { Chalofsky } \\
\text { significant work } \\
\text { environment }\end{array}$ & $\begin{array}{c}\text { MOW } \\
\text { dimensions }\end{array}$ \\
\hline $\begin{array}{l}\text { Aspects/ } \\
\text { Variables }\end{array}$ & $\begin{array}{l}\text { Significance: } \\
\text { work definition } \\
\text { and centrality in } \\
\text { a certain } \\
\text { moment in time. } \\
\text { Orientation: } \\
\text { values pursued } \\
\text { at work. } \\
\text { Coherence: } \\
\text { intellectual, } \\
\text { emotional and } \\
\text { behavioral } \\
\text { alignment with } \\
\text { work } \\
\text { (competencies } \\
\text { aligned to } \\
\text { function). }\end{array}$ & $\begin{array}{l}\text { Variety of tasks: } \\
\text { usage of several } \\
\text { competencies. } \\
\text { Work identity: } \\
\text { ability to perform } \\
\text { something from the } \\
\text { beginning to the } \\
\text { end, with an } \\
\text { identifiable and } \\
\text { tangible result. } \\
\text { Work significance: } \\
\text { possibility of } \\
\text { generating } \\
\text { significant impact on } \\
\text { well-being or work } \\
\text { of other people. } \\
\text { Autonomy: } \\
\text { freedom to perform } \\
\text { tasks and } \\
\text { accountability for } \\
\text { established and } \\
\text { achieved objectives. } \\
\text { Feedback: } \\
\text { information on } \\
\text { performance } \\
\text { allowing } \\
\text { adjustments. }\end{array}$ & $\begin{array}{l}\text { Work: individual } \\
\text { perceptions of } \\
\text { work: purpose, } \\
\text { learning, } \\
\text { autonomy and } \\
\text { locus of control. } \\
\text { Individual: } \\
\text { expressions of } \\
\text { purpose, beliefs, } \\
\text { self-control and } \\
\text { drive. } \\
\text { Balance: } \\
\text { management of } \\
\text { tensions } \\
\text { between work } \\
\text { and life. }\end{array}$ & $\begin{array}{l}\text { Centrality: degree of } \\
\text { important of work in life, } \\
\text { in a certain moment in } \\
\text { time. } \\
\text { Social rules: beliefs and } \\
\text { expectations on duties } \\
\text { (individual and collective } \\
\text { obligations) and rights } \\
\text { (exchanges between } \\
\text { individual and } \\
\text { organization). } \\
\text { Valid results: expected } \\
\text { results or reasons to } \\
\text { work. } \\
\text { Preferences/ objectives: } \\
\text { hierarchy of instrumental } \\
\text { and final values pursued } \\
\text { at work. } \\
\text { Identification with } \\
\text { work: interpretation of } \\
\text { work according to } \\
\text { individual psychological } \\
\text { identification. }\end{array}$ \\
\hline
\end{tabular}


(Figure 2.3.1 (conclusion))

SYNTHESIS OF MEANING OF WORK MODELS

\begin{tabular}{|c|c|c|c|c|}
\hline & $\begin{array}{c}\text { Morin } \\
\text { components }\end{array}$ & $\begin{array}{c}\text { Hackman \& } \\
\text { Oldham } \\
\text { work design }\end{array}$ & $\begin{array}{l}\text { Chalofsky } \\
\text { significant work } \\
\text { environment }\end{array}$ & $\begin{array}{c}\text { MOW } \\
\text { dimensions }\end{array}$ \\
\hline $\begin{array}{l}\text { Origin/ } \\
\text { Purpose }\end{array}$ & $\begin{array}{l}\text { Arises from the } \\
\text { agglutination } \\
\text { of definitions } \\
\text { of meaning of } \\
\text { work (Yalon, } \\
\text { 1980, as cited } \\
\text { in Morin, 2008, } \\
\text { p. 3) }\end{array}$ & $\begin{array}{l}\text { Arises to explain } \\
\text { motivation, } \\
\text { satisfaction and } \\
\text { work productivity, } \\
\text { interacting job } \\
\text { characteristics and } \\
\text { individual } \\
\text { differences. }\end{array}$ & $\begin{array}{l}\text { Arises from } \\
\text { reflections } \\
\text { anchored in } \\
\text { humanist theory } \\
\text { emphasizing } \\
\text { intrinsic } \\
\text { motivation and } \\
\text { growth from } \\
\text { learning. }\end{array}$ & $\begin{array}{l}\text { Arises to sustain a } \\
\text { research articulating } \\
\text { different conceptions: } \\
\text { - central interest in life } \\
\text { (Kanungo, 1982, Sakek } \\
\text { \& Hosek, 1976, Wall, } \\
\text { Cook, \& Wall, 1979, as } \\
\text { cited in Ruiz-Quintanilla } \\
\text { \& Claes, 2000, p. 353). } \\
\text { - work ethics (Kaplan \& } \\
\text { Tausky, 1974, as cited } \\
\text { in Ruiz-Quintanilla \& } \\
\text { Claes, 2000, p. 341). } \\
\text { - values (Rokeach, 1973, } \\
\text { Ruiz--Quintanilla \& } \\
\text { Mainer as cited in Ruiz- } \\
\text {-Quintanilla \& Claes, } \\
\text { 2000, p. 353). } \\
\text { - job design (Emery, } \\
\text { 1964, 1976, Trist, } \\
\text { 1978, as cited in Morin, } \\
\text { 2008, p. 11) }\end{array}$ \\
\hline
\end{tabular}

Source: Elaborated by the author based on Chalofsky (2010), Hackman and Oldham (1976), Morin (2004, 2008),

and Ruiz-Quintanilla and Claes (2000).

All models focus on labor values and aspects of the execution of the activity/work. Besides Chalofsky's model that emphasizes the individual, all models include individual and organizational aspects. Hackman and Oldham's model emphasizes the design and the exercise of the activity/ function with a social and technical approach. It has been quoted and explored over the last 40 years. Chalofsky (2010) criticizes the organizational philosophy of result by result and the organizational and careers hierarchical model. Morin's and MOW models tend to balance individual and organization and search for continuous interaction between the two. The use or support of one or another model depends on the type of study realized (objective, theoretical framework, and investigation method). 


\subsection{Studies on the meaning of work}

Researchers took very different paths and approaches throughout the last 50 years when studying the meaning of work, and these paths varied according to their scientific background (psychology, philosophy, business, etc.). The discussion is active in symposiums and congresses, but less reflected in available scientific resources. Theoretical works emphasize concepts and determinants of the meaning of work, and empirical studies focus on specific work/cultural locations and specific professional jobs/careers.

Theoretical papers reflect the importance of beliefs, values, and ethics at work (Heller \& Ruiz-Quintanilla, 1995; Rosso et al., 2010), analyze the changes in meaning of work throughout history (Kuchinke, 2009; Ardichivili \& Kuchinke, 2009), and discuss the interaction of people as a contemporary source of meaning at work (Rohm \& Lopes, 2015).

A good proportion of recent studies on the meaning of work reinforce two MOW dimensions-centrality and valid results, either by elaborating the research hypothesis or by analyzing emerging results. Work centrality is high in almost all researched countries (Belgium, Brazil, China, German, Holland, Hong Kong, Hungary, Israel, Japan, Kazakhstan, Poland, Russia, USA, and Yugoslavia), despite cultural differences among them (Kuchinke, 2009; Kuchinke, Ardichvili, Borchet, \& Rozanski, 2009; Kuchinke et al., 2011).

When discussing valid results, the studies point to the substantive meaning of work (autonomy, relationships, learning, development, and recognition) and also to the instrumental meaning of work (subsistence, financial return and safety) (Lemos \& Cazavotte, 2017; Rodrigues, Barrichello, Irigaray, Soares, \& Morin, 2017; Silva \& Simões, 2015). It seems that the perception of substantive or instrumental meaning of work is related to specific professional categories or careers. In non-rewarded work, such as voluntarism, the substantive meaning is related to identification with the institution (Borchardt \& Bianco, 2016).

Without investigating empirically, some researchers argue that the perception of the meaning of work may influence organizational variables such as absenteeism, satisfaction, stress, individual performance, commitment, work environment, change in management, resilience, decision-making processes, and creativity (Holbeche \& Springht, 2004; Rosso et al., 2010; Ulrich \& Ulrich, 2011). This last argument justifies the importance of the subject currently. 


\section{RESEARCH METHOD}

The objective of this research is to examine how professionals in managerial positions in Brazilian organizations perceive and define the meaning of work. The research approach is a mixed method (Creswell, 2013), using on a sequential way of inquiring both qualitative and quantitative methods. Theories on the subject support the deductive way of investigating (Selltiz, Wrightsman III, \& Cook, 2007) while an inductive analysis complements the exploratory data analysis. The MOW model was used as the theoretical framework due to its conceptual comprehension. The dimension social rules were not studied due to the survey subject. This dimension includes elements of the operational relationship between companies and employees, not necessarily applicable to managers (the MOW model has been used in its entirety or partially by a significant group of researchers around the world, depending on researcher's focus and subject).

The study was conducted in four businesses of Ultrapar: 1. Ipiranga; 2. Ultragaz (fuel distribution); 3. Oxiteno (chemicals); and 4. Ultracargo (liquid bulk storage) and the holding structure. Figure 3.1 presents the research process including data collection methods, sources of data, and data treatment (Martins \& Theóphilo, 2009; Pestana \& Gageiro, 2008).

\section{(Figure 3.1)}

RESEARCH METHOD

\begin{tabular}{|c|c|c|c|c|}
\hline Specific objective & Method & Source of data & Data collected & Data treatment \\
\hline $\begin{array}{l}\text { Access } \\
\text { organizational } \\
\text { contingencies and } \\
\text { implications for } \\
\text { managers. }\end{array}$ & $\begin{array}{l}\text { In-depth } \\
\text { interview. } \\
\text { Documental } \\
\text { analyses. }\end{array}$ & $\begin{array}{l}\text { Businesses } \\
\text { presidents and } \\
\text { CFO } \\
\text { ( } \mathrm{n}=6 \text { people). } \\
\text { Internet, intranet } \\
\text { and internal } \\
\text { surveys }\end{array}$ & $\begin{array}{l}\text { Key internal and } \\
\text { external } \\
\text { contingencies } \\
\text { on people } \\
\text { management. } \\
\text { Companies profiles } \\
\text { and engagement } \\
\text { survey. }\end{array}$ & $\begin{array}{l}\text { Data } \\
\text { registration, } \\
\text { transcription and } \\
\text { analyses (further } \\
\text { triangulation). }\end{array}$ \\
\hline $\begin{array}{l}\text { Access perception/ } \\
\text { definition of } \\
\text { meaning of Work. }\end{array}$ & $\begin{array}{l}\text { Online } \\
\text { questionnaire } \\
\text { (MOW- } \\
\text { questionnaire C). }\end{array}$ & $\begin{array}{l}\text { Managers of the } \\
\text { organizations } \\
(\mathrm{N}=852 \\
\mathrm{n}=291)\end{array}$ & $\begin{array}{l}\text { Scores on the } \\
\text { model's variables. }\end{array}$ & $\begin{array}{l}\text { Measures of } \\
\text { dispersion, } \\
\text { Friedman test, } \\
\text { binary } \\
\text { correlation, and } \\
\text { cluster analysis. }\end{array}$ \\
\hline
\end{tabular}




\section{(Figure 3.1 (conclusion))}

RESEARCH METHOD

\begin{tabular}{|c|c|c|c|c|}
\hline Specific objective & Method & Source of data & Data collected & Data treatment \\
\hline $\begin{array}{l}\text { Deepen the } \\
\text { analysis about } \\
\text { perceptions of } \\
\text { meaning of work. }\end{array}$ & Focus group. & $\begin{array}{l}\text { Six groups (each } \\
\text { company, holding } \\
\text { and a mixed one) } \\
\mathrm{n}=56 \text { managers } \\
\text { (19 had not } \\
\text { completed the } \\
\text { questionnaire). }\end{array}$ & $\begin{array}{l}\text { Confirmation, } \\
\text { explanation and } \\
\text { reflections on the } \\
\text { data from } \\
\text { questionnaires. }\end{array}$ & $\begin{array}{l}\text { Data registration } \\
\text { and analysis } \\
\text { (further } \\
\text { triangulation). }\end{array}$ \\
\hline
\end{tabular}

The reliability of the research, determined by the consistency of the results (Martins, 2006), was addressed by confirming the understanding of the answers and reflections made in the interviews and in the focus groups. In addition, the questionnaire was pre-tested (translation of all content, test of the understanding of the assertions by 25 specialists/managers, use of the technological resource (see www.surveymonkey.com), followed by reliability test $(\alpha$-Cronbach $=0,726)$, and the process was also associated with the validity of the construction (Selltiz, Wrightsman III, \& Cook, 2010).

\section{RESULTS AND ANALYSES}

The results are presented and discussed in the following order: context (internal and external contingencies affecting people management at the organizations), perception/definition meaning of work (analyzing each dimension of the model and its integration), and organizational implications.

\subsection{Context: contingencies related to people management}

Ultrapar is a Brazilian group with more than 80 years of history. The group has shown performance and sustainable growth, distinguishing itself by maintaining leadership positions in the markets in which it operates. The key enablers of its position are consistent strategy planning and execution, discipline in capital allocation, reinforcement of a results-driven culture, adoption of a governance model, and portfolio of resilient businesses (Ultra, 2016). The multi-business structure stimulates people's mobility and allows knowledge sharing and best practices dissemination. In addition, meritocracy 
and alignment of interests between leaders and employees are two main pillars in the people management strategy (Ultra, 2016).

The CEO and the presidents of the four businesses (Ultragaz, Ipiranga, Oxieno, and Ultracargo) reflected on the main challenges related to external contingencies. They reinforced sustainable growth in a more volatile and lower growth market. E-commerce appeared as a new challenge, but technology was not seen as a modifying factor in work execution. They also mentioned stakeholders as an important new area of attention that demands time and more communications skills. Around demographic and social changes, the executives cited attracting and retaining talents, management of internal relationships, succession process at " $\mathrm{C}$ " level, management in and with different businesses cultures, maintenance of cohesion, motivation and clarity of purposes and management of multiple generations as important factors. Except the multiple generations, the subjects permeated all the companies. These challenges are consistent with the economic, social, and demographic changes and technology breakthroughs (PwC, 2018) discussed.

As regards the managers, the executives reported that all challenges tended to increase the complexity of the management process. The managers have to balance pressure, assertiveness, and care to insure the readiness of work teams. In their perception, their managers expect to gain realization, recognition, balance with other areas in life, and personal growth from their work.

\subsection{Sample profile}

In total, 291 people answered the online questionnaire: 94 professionals from Ipiranga, 52 from Oxiteno, 24 from Ultracargo, 93 from Ultragaz, and 24 from the corporate financial area. The distribution of the participants in the sample is very similar to the distribution of the management population. As regards education, $89.1 \%$ of the managers have a college education level or above and $62 \%$ of whom have specialization, masters, or doctoral degrees. The largest majority of the managers are male: $73.2 \%$. As regards age, $77.3 \%$ are between 31 to 50 years. In addition, $48.4 \%$ of the managers have up to three years in their current position. The participants in the focus groups argued that this last data results from the high internal mobility (perceived people management strategy in practice). Because of the location of plants and branches throughout Brazil, managers represent all regions of the country, with high concentrations in Rio de Janeiro and São Paulo (75\%). 


\subsection{Meaning of work for the managers}

As suggested by the MOW model, this study analyzes each of the variables before observing the full perception of the respondents on the meaning of work. The analyses include statistical treatment of the variables, perceptions/insights of the participants in the focus groups, and triangulation.

\subsection{Centrality}

Centrality refers to the degree of importance that work has in people's lives in a relative or absolute way (Ruiz-Quintanilla \& Claes, 2000). Figure 4.4.1 condenses data from the questionnaire and the focus groups and includes some theoretical arguments.

\section{(Figure 4.4.1)}

\section{ABSOLUTE AND RELATIVE WORK CENTRALITY}

\begin{tabular}{|c|c|c|c|c|}
\hline & \multicolumn{3}{|c|}{ Relative work centrality } & Absolute work centrality \\
\hline \multirow[t]{3}{*}{$\begin{array}{l}\text { Data from } \\
\text { questionnaire }\end{array}$} & \multicolumn{3}{|c|}{$\begin{array}{l}\text { Importance in life (distribution of } 100 \\
\text { points) }\end{array}$} & $\begin{array}{l}\text { Responses based on concordance } \\
\text { scale. }\end{array}$ \\
\hline & \multicolumn{3}{|c|}{ Average points/Coefficient of variation } & \multirow[b]{2}{*}{$\begin{array}{l}\text { According to the respondents: } \\
\text { - } 94,5 \% \text { of them are personally very } \\
\text { involved with work; } \\
\text { - } 83,9 \% \text { of them even if won the } \\
\text { lottery would continue to work; } \\
\text { - } 86,1 \% \text { of them would be bored if did } \\
\text { not have a work to do; } \\
\text { - } 44,6 \% \text { of them say that the most } \\
\text { important things that happen to } \\
\text { then, involve work. }\end{array}$} \\
\hline & $\begin{array}{l}\text { Family } \\
\text { Work } \\
\text { Leisure } \\
\text { Spirituality } \\
\text { Community } \\
\text { * High variar } \\
\text { spirituality a } \\
\text { the low hom }\end{array}$ & $\begin{array}{l}34.1 \\
32.1 \\
15.4 \\
11.8 \\
7.6 \\
\text { es in th } \\
\text { d comm } \\
\text { geneity }\end{array}$ & $\begin{array}{l}30 \% \\
41 \% \\
43 \% \\
68 \% * \\
69 \% \\
\text { esponses for } \\
\text { ity reinforces } \\
\text { responses. }\end{array}$ & \\
\hline \multirow{2}{*}{$\begin{array}{l}\text { Reflections } \\
\text { from the } \\
\text { focus groups }\end{array}$} & \multirow{2}{*}{\multicolumn{3}{|c|}{ 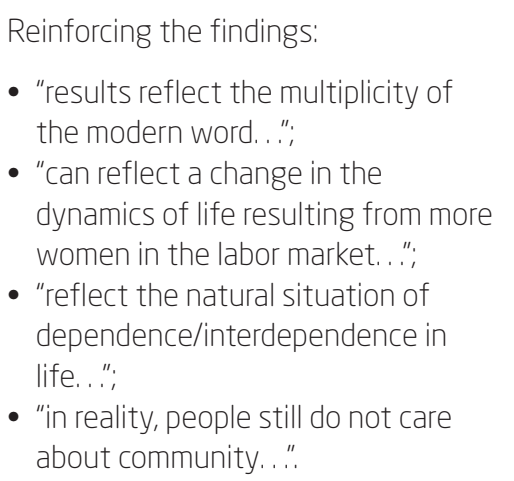 }} & Debating the findings: \\
\hline & & & & $\begin{array}{l}\text { - "may be age would impact the } \\
\text { findings..." (argument not confirmed } \\
\text { by data analyses); } \\
\text { - "just a few people celebrate work } \\
\text { anniversary, but marriage and } \\
\text { children, they do...." }\end{array}$ \\
\hline
\end{tabular}




\section{(Figure 4.4.1 (conclusion))}

\section{ABSOLUTE AND RELATIVE WORK CENTRALITY}

\begin{tabular}{|c|c|c|}
\hline & Relative work centrality & Absolute work centrality \\
\hline $\begin{array}{l}\text { Theoretical } \\
\text { arguments } \\
\text { and other } \\
\text { findings }\end{array}$ & $\begin{array}{l}\text { Cabral (2011), when relativize the } \\
\text { work, realize the growing importance } \\
\text { of the family. }\end{array}$ & $\begin{array}{l}\text { Ruiz-Quintanilla and Claes (2000) } \\
\text { researched that 90\% of the individuals } \\
\text { had moderated to high absolute work } \\
\text { centrality. In addition, Morse and Weiss } \\
\text { (as cited in Vecchio, 1980, p. 362) } \\
\text { reported that } 80 \% \text { of the respondents } \\
\text { if had enough money to live } \\
\text { conformability without work, would } \\
\text { work anyway. }\end{array}$ \\
\hline
\end{tabular}

Source: Elaborated by the author.

For this sample, work centrality is high, but when balanced with family, shows equilibrium. In other words, there is balance between family and work with a high involvement of the individual with work. This finding reflects Dejours' (2009) contemporary perception of work and aligns with the findings of Kuchinke et al. (2009).

\subsection{Valid results}

Valid results explore the reasons for working (Ruiz-Quintanilla \& Claes, 2000). Descriptively, based on the average of the answers, there are two groups of results. Group one, with higher averages, consists of "the work provides me the income I need", "the work itself is an interesting activity", and "that satisfies me". The second group, with much lower averages, includes "work allows me to have interesting contacts with others", "helps me to serve the community", "brings status and prestige", and "keeps me occupied". Despite the high dispersion in the answers in the questionnaires, in all focus groups, the participants agreed and had no new inputs. The central ideas of group one, income and interesting activity, represent the economic and the expressive results of the work, respectively (Carochinho, 2009; Ruiz-Quintanilla \& Claes, 2000). This finding supports the research of Lemos and Cazavotti (2017) and Rodrigues et al. (2017). In addition, one argument of group two aligns with the contemporary source of meaning at work raised by Rohm and Lopes (2015)_interaction with people. 


\subsection{Objectives and preferences}

Objectives and preferences reflect the relative preference of people regarding labor values (Ruiz-Quintanilla \& Claes, 2000). Respondents ordered sixteen values. Using the Friedman test, with $\chi^{2}=1241, \mathrm{p}=0.000$, the hypothesis of same importance for all expressions was rejected (Pestana \& Gageiro, 2008). Still, through multiple comparisons, it was possible to distinguish between important and less important expressions. When the difference was greater than msd $=393.49$ (minimal significant difference), the terms differed in terms of importance. Figure 4.6.1 presents the results.

\section{(Figure 4.6.1)}

ORDER OF RELEVANCE: OBJECTIVES AND PREFERENCES

\begin{tabular}{lcc}
\hline \multicolumn{1}{c}{ Assertive } & Total score & $\begin{array}{c}\text { Grouping according } \\
\text { to degree of } \\
\text { importance }\end{array}$ \\
\hline An INTERESTING work (something that you really like to do) & 1259 & A \\
A good SALARY & 1539 & A \\
Many opportunities for LEARNING & 1589 & A \\
RECOGNITION for doing a good job & 1647 & A \\
Good opportunities for growth and PROMOTION & 2035 & B \\
Good INTERPERSONAL relationships with work colleagues & 2233 & BC \\
Good BENEFITS & 2342 & BC \\
Good PROFESSIONAL relationship with superiors & 2377 & BC \\
A lot of AUTONOMY (decision on how and what to do) & 2411 & BC \\
A good ALIGNMENT between the requirements of the & 2486 & C \\
function and his/her Skills and competencies & 3018 & D \\
Good work CONDITIONS (noise, cleanliness, sounds...) & 3166 & D \\
An INFLUENTIAL position in the Organization & 3206 & D \\
Large VARIETY of activities & 3224 & DE \\
SECURITY in employment & 3439 & E \\
Contribution to SOCIETY though of his/her work & 3605 & E \\
CONVENIENT work hours & & \\
\hline
\end{tabular}

Source: Elaborated by the author.

The dichotomy of extrinsic and intrinsic labor values remains (Porto \& Tamayo, 2008). Despite this, according to Ruiz-Quintanilla and Claes (2000), economic objectives are related to extrinsic values (results of the work) while expressive objectives are related to intrinsic values (content of the work). For this sample, intrinsic values are more relevant (groups A and B) than extrinsic 
values (groups D and E), with the exception of salary. Focus group participants were surprised by the relatively low relevance of autonomy and understood that the variety of activities can be related to interesting work (first relevance). The use of technology in work, a new reality, appears to be inconsistent with convenient work hours, disrupting the separation between life and work (PwC, 2018).

The values (objectives and preferences) elected by this group of professionals are aligned with the research on organizational people behavior (Crabtree, 2013; HayGroup, 2013; SHRM, 2017; Ulrich \& Ulrich, 2011). They fill some gaps that disconnect professionals from their organizations (lack of recognition, unpleasant execution of the work, poor internal relationships and few opportunities).

\subsection{Work identity}

Work identity approaches different interpretations and notions of work. Ruiz-Quintanilla and England (1994) divide the fourteen items that support work identification according to four different criteria: Responsibility and Exchange (RE), Social Contribution (SC), Restrictions to Performance at Work (RP) and Stressors (ST). Figure 4.7.1 presents the concordance of respondents with the items and reflections based on the authors' criteria.

\section{(Figure 4.7.1) \\ WORK IDENTITY EXPRESSIONS}

\begin{tabular}{lccll}
\hline \multicolumn{1}{c}{$\begin{array}{c}\text { An activity is considered } \\
\text { work when... }\end{array}$} & $\begin{array}{c}\text { Agreement } \\
(\mathbf{\%})\end{array}$ & Criteria & \multicolumn{1}{c}{ Consideration } \\
\hline $\begin{array}{l}\text { It adds value to something or someone. } \\
\begin{array}{l}\text { Through it, I develop a sense of } \\
\text { belonging to some organization. }\end{array}\end{array}$ & $\begin{array}{l}91 \\
\text { I receive a salary for it. }\end{array}$ & SC & SC & $\begin{array}{l}\text { Positive expression of the } \\
\text { work based on social }\end{array}$ \\
I am accounted for its results. & 88 & RE & $\begin{array}{l}\text { contribution, responsibility } \\
\text { and exchange. }\end{array}$ \\
\hline It is mentally demanding. & 88 & RE & \\
I realize to contribute to society. & 58 & RE & Positive expression of the \\
Others benefit from it. & 55 & SC & work based on social \\
It belongs to my daily activities. & 54 & SC & contribution, responsibility \\
\hline
\end{tabular}


(Figure 4.7.1 (conclusion))

WORK IDENTITY EXPRESSIONS

\begin{tabular}{lcll}
\multicolumn{1}{c}{$\begin{array}{c}\text { An activity is considered } \\
\text { work when. . }\end{array}$} & $\begin{array}{c}\text { Agreement } \\
(\mathbf{\%})\end{array}$ & Criteria & \multicolumn{1}{c}{ Consideration } \\
\hline $\begin{array}{l}\text { I realize in a certain period (for example } \\
\text { from 9AM to 6 PM). }\end{array}$ & 28 & RP & $\begin{array}{l}\text { Negative expression of the } \\
\text { work based mainly on }\end{array}$ \\
I am obliged to realize. & 25 & ST & $\begin{array}{l}\text { restrictive aspects to } \\
\text { I perform in a workplace. }\end{array}$ \\
\hline Someone tells me what to do. & 18 & RP & performance. \\
It is physically demanding. & 8 & ST & Negative expression of the \\
It is not pleasant. & 5 & RP & work based mainly on \\
\hline
\end{tabular}

Source: Elaborated by the author.

For this sample, all criteria are present in work identification with a clear positive expression of work. This perception is in line with Ruiz-Quintanilla and England's studies, carried out from 1982 to 1991. The studies' results varies from country to country, but always tends to be positive (the perception is more related to social contribution in eastern countries and more related to responsibility and exchange in western ones). In addition, as argued by Dourado et al. (2009), from an economic bias, in today's society, work cannot be negative.

\subsection{Definition of meaning of work}

The definition of the meaning of work was verified through cluster analysis (Ward method followed by the non-hierarchical method K-means) (Hair, Black, Badin, Anderson, \& Tatham, 2009; Pereira, 2004) by classifying the respondents into different groups, each of which was internally homogeneous, externally heterogeneous, and mutually exclusive (Fávero, Belfiore, Silva, \& Chan, 2009).

Objectives and preferences, for being an ordinal variable, were considered afterwards, in the analysis of binary correspondence, as a variable characterizing the clusters. The correspondence analysis also included the respondent's socio-demographic profile, when variables had statistical significance $\left(\chi^{2}\right.$ test $(p \leq 0.05)$ ) (Pestana \& Gageiro, 2008). Despite one dimension of the correspondence analysis explaining the largest part of the data variance $(61 \%)$, the three dimensions were used, combined two by two 
in perceptual maps to support the results comprehension. Figure 4.8.1 shows the definitions of the meaning of work found for the sample combining the two multivariate data analysis techniques.

\section{(Figure 4.8.1) \\ MEANING OF WORK DEFINITIONS}

\begin{tabular}{|c|c|c|}
\hline Cluster & Characteristics & Respondents \\
\hline $\begin{array}{c}\text { Central in } \\
\text { Life }\end{array}$ & $\begin{array}{l}\text { Work is done in an organization, in which a contract and a } \\
\text { positive exchange relationship is established (accountability } \\
\text { for processes and outcomes as well as mutual value added } \\
\text { are expected and a salary is received). Work is important in } \\
\text { daily activities, is mentally demanding, and a very pleasant } \\
\text { activity. Others benefit from the product of work and, } \\
\text { eventually, society as well. In individual terms, work may } \\
\text { sometimes be more central than the family, since there is a } \\
\text { high personal involvement with it. Growth and promotion are } \\
\text { expected as results of the work. Restrictive factors such as } \\
\text { fixed working hours and a feeling of obligation are not } \\
\text { intensively perceived, but in some cases, they may be part of } \\
\text { what is considered work. An individual sometimes perceives } \\
\text { that the most important things that happen are related to it } \\
\text { and would continue to work, even if he/she did not need to } \\
\text { work to maintain his/her survival. Proportionally, more females } \\
\text { belong to this group. }\end{array}$ & $\begin{array}{c}108 \\
\text { (40.5\% of } \\
\text { total sample) }\end{array}$ \\
\hline $\begin{array}{l}\text { Regular } \\
\text { Rewarded } \\
\text { Activity }\end{array}$ & $\begin{array}{l}\text { Work, in a certain moment, is a job. It belongs to the daily } \\
\text { activities, is realized at a place, in a company, and may be } \\
\text { physically demanding. Accountability is mandatory and the } \\
\text { exchange are status, prestige, promotions, new opportunities, } \\
\text { and salary. It may reflect in society, in others, but this is not } \\
\text { the focus. It is relatively more important than family since the } \\
\text { most important things happening in life involve work. Certain } \\
\text { restrictions are accepted as hierarchy, a feeling of obligation, } \\
\text { and strict compliance with work hours. Pleasure is part of it, } \\
\text { but it may not be present. With all the subsistence conditions } \\
\text { met, a professional would stop working. The general feeling } \\
\text { as regards work is neutrality, a way for achieving other } \\
\text { purposes. }\end{array}$ & $\begin{array}{c}71 \\
\text { (24.5\% of } \\
\text { total sample) }\end{array}$ \\
\hline
\end{tabular}




\section{(Figure 4.8.1 (conclusion)) MEANING OF WORK DEFINITIONS}

\begin{tabular}{|c|c|c|}
\hline Cluster & Characteristics & Respondents \\
\hline $\begin{array}{l}\text { Benefit } \\
\text { Others }\end{array}$ & $\begin{array}{l}\text { Work is an activity realized to contribute to society and other } \\
\text { people always take benefit and value. Work does not mean } \\
\text { status or prestige, is not as important as other areas of life } \\
\text { and does not necessarily mean salary, promotion or restrictive } \\
\text { rules (hierarchy, place and specific hours). On the other hand, } \\
\text { interpersonal relationships throughout the process are } \\
\text { important as well as a sense of accomplishment of social } \\
\text { duty. Work is not related to survival or subsistence conditions, } \\
\text { but it is lived and performed almost as a vocation. }\end{array}$ & $\begin{array}{c}36 \\
\text { (12.4\% of } \\
\text { total sample) }\end{array}$ \\
\hline $\begin{array}{l}\text { Individualism } \\
\text { in Work }\end{array}$ & $\begin{array}{l}\text { Work is an activity with very large relative importance, which } \\
\text { adds value to the individual himself. Rules such as location, } \\
\text { hierarchy, routine, pre-established hours and other stressors } \\
\text { are not part of what work is. The benefit is always personal; } \\
\text { others or society are not considered. Status, prestige, and } \\
\text { promotions are not valued, although the work can be } \\
\text { performed in an organization. It must clearly contribute to the } \\
\text { individual, but only to him in a relationship of autonomy and } \\
\text { personal self-sufficiency. Proportionally, more males belong } \\
\text { to this group. }\end{array}$ & $\begin{array}{c}66 \\
\text { (22.9\% of } \\
\text { total sample) }\end{array}$ \\
\hline
\end{tabular}

Source: Elaborated by the author.

There is not a single definition of the meaning of work for this sample, even though valid results and relative centrality can be considered as common traces among the clusters. Age and tenure in position did not influence the formation of the groups.

When comparing the clusters found in this research with the standards of work definition from England and Whiteley (1990, as cited in Morin, 2001, p. 12), there are three similarities: Standard B (Central in Life), Standard C (Benefit Others) and Standard F (Regular Rewarded Activity).

The cluster Central in Life offers a broad view of work, emphasizing the economic perspective and positioning work as a fundamental reference to the individual (Bianchi, 2013; Dourado et al., 2012; Morin \& Aubé, 2008). Already, the cluster Regular Rewarded Activity portrays an instrument and exchange, part of an organized economic system, fundamental to the achievement of other objectives (Bertoncelo \& Junqueira, 2018; Morin, 2008). The cluster Benefit Others is more aligned to a call, the vocation to be achieved leading to a greater benefit for the society (Dik et al., 2014, Martin, 2010; Rosso et al., 2010). 
The cluster Individualism in Work did not find support in the seminal literature. It may represent a more contemporary vision of work and may be related to aspects of the competitive scenario (SHRM, 2014) and to characteristics of modernity like individuality, emancipation, and individualism at work, according to Bauman (2000). Also, this cluster may be aligned with new perspectives on a career that emphasizes autonomy and the "I entrepreneur", the one who uses work to make life an adventure, projects himself into the future, and gives himself a form so as to become what he/she wishes to be (Lemos, 2013). The results reinforce multiple meanings and orientations of work discussed by the theory supporting this study.

\subsection{Organizational implications}

Although the level of significance is slightly higher than $5 \%$ and less than $10 \%$ in the $\chi^{2}$ test $\left(\chi^{2}=20.242, p=0.063>0.05\right)$, a non-homogeneous cluster distribution was verified among the researched organizations. The Central in Life cluster was mainly observed in Ipiranga (46\%) and in Oxiteno (48\%). In Oxiteno, the cluster Benefit the Other appeared more ( $36 \%$ of total cases). In Ultragaz, the cluster Individualism in Work appeared more ( $41 \%$ of total cases), and in Ultracargo and holding financial department, the predominant cluster was Regular Rewarded Activity (42\% and $38 \%$, respectively). Since the meaning of work is mainly an individual perception, which contradicts the findings of Kuchinke et al. (2009) of no relationship between the meaning of work and organizations, this research may have found something different. Individuals seek a company where they can experience their demands, or the company would shape individual's perceptions.

When challenged around these issues, the focus group participants argued that companies search for employee's profile (values, style, and competencies) when hiring a new professional. Then, throughout their working life, a process of natural selection and adaptation takes place, and employees choose to stay or not in a particular company in a given condition/situation. In the end, people find the environment that best suits them. In addition, some organizational cultures and company values facilitate the insertion and maintenance (socialization) of determinate employees' profiles.

Another important issue that arises from these findings centers around the management role. Different individual perceptions on work are certainly reflected in management style, especially when considering the management 
of people. Individual meaning of work would affect day-to-day activities, especially the exercise of organizational values and deployment of human resource practices (recognition, autonomy, development. . .).

\section{FINDINGS AND DISCUSSION}

The meaning of work is not a new construct. Although studied for decades, it remains contemporary and well suited to the current competitive scenario, perhaps even more critical. On one hand, it contributes to clarifying people's work demands and expectations. On the other hand, it can help organizations to deepen their knowledge of their employees and become a better work value proposition.

The MOW model appeared to be contemporary and adequate for use in the Brazilian culture. As a contribution, this study validated the MOW scale, making available another theoretical approach to research on meaning of work, besides ETS (Escala do Trabalho com Sentido) validated by Bendassolli and Borges-Andrade (2015). The study also found a new category of the meaning of work-Individualism in Work. Most likely, this category is related to modernity and the changes in the society that require and encourage more independence and autonomy.

Although recognized as a pleasant paid activity of high centrality in life and full of intrinsic values, the work has different interpretations among managers as shown by this study. The interpretations differ based on where the work is executed, whom it benefits, extrinsic values expectations, and the ability to handle stress factors. Tenure or age do not influence interpretations of work, but gender does. This result is expected since meaning is an individual interpretation, but it may bring some implications to the daily management function. If the instrumental meaning of work becomes as important as the substantive meaning of it, the manager may focus more on processes than on people and, in turn, give less attention to the intrinsic values of their subordinates. A high instrumental meaning of work can also affect the definition and implementation of people management practices. Thus, the meaning of the work of managers has organizational implications.

In contrast to other international studies, this work has found a possible relationship between the meaning of work and organizational culture. This expands the notion of the relationship between national culture and the meaning of work to the organization as well. Apparently, the adaptation/ shaping binomial relationship between employee and organization is mediated by shared intrinsic and extrinsic values of the work. 
Due to these findings, the relationships between the meaning of work and management style and meaning of work and organizational culture justify new studies and may contribute greatly to the development of the fields of organizational behavior and people management. All research approaches are valid as well as research subjects (managers, staff, local organizations or multinational organizations).

The topic is provocative, critical and contemporary, and deserves proper scholarly attention to support the development of organizations and their professionals in a way that meaning, meaning of work, purpose, connection, engagement, recognition, commitment, respect, and involvement become topics discussed in a very positive way in both organizational studies and practical organizational survey in the coming years.

\section{O SENTIDO DO TRABALHO PARA GESTORES BRASILEIROS NO CONTEXTO ORGANIZACIONAL CONTEMPORÂNEO}

\section{RESUMO}

Objetivo: Verificar como gestores brasileiros definem o significado do trabalho, iniciando uma reflexão sobre decorrentes implicações organizacionais.

Originalidade/relevância: Este estudo endereça duas oportunidades de pesquisa. Expande a temática sentido do trabalho para além das categorias profissionais, enfatizando a organização e a posição gerencial e complementa o campo da pesquisa sobre gestores que está prioritariamente centrado em desenvolvimento pessoal e a execução do papel organizacional.

Principais aspectos metodológicos: A abordagem de pesquisa é de métodos mistos, usando sequencialmente, métodos qualitativos e quantitativos de investigação (entrevista, questionário e grupo focal). Considerando todas as fases, 316 gestores e executivos participaram da pesquisa. Variáveis do modelo Meaning of Work (MOW) fundamentaram o processo de coleta de dados. Para tratamento dos dados foram utilizadas estatística descritiva e inferencial e análise multivariada de dados.

Síntese dos principais resultados: O trabalho, embora reconhecido como uma atividade remunerada de alta centralidade na vida e fonte de valores 
intrínsecos (reconhecimento, autonomia, oportunidades de aprendizagem), possui diferentes interpretações dependendo de onde o trabalho é executado, quem se beneficia dele, das expectativas de valores extrínsecos e da capacidade para lidar com fatores de estresse. Diferentemente de outros estudos internacionais, este trabalho encontrou possíveis relações de sentido do trabalho e cultura organizacional. O sentido do trabalho dos gestores tem implicações organizacionais, impactando o trabalho diário, os estilos gerenciais e a implementação de práticas de gestão de pessoas.

\section{PALAVRAS-CHAVE}

Sentido. Sentido do trabalho. Gerentes. Organizações. Sentido do trabalho para gestores.

\section{REFERENCES}

Amaral, R. A. (2008). O sentido do trabalho: Visões de um problema nos séculos $X I X$ e XX (Doctoral dissertation). Retrieved from http://www.teses.usp. br/teses/disponiveis/8/8138/tde-20032009-161547/pt-br.php

Andrade, S. P. C., Tolfo, S. R., \& Dellagnelo, E. H. L. (2012). Sentidos do trabalho e racionalidades instrumental e substantiva: Interfaces entre a administração e a psicologia. Revista de Administração Contemporânea, 16(2), 200-216.

Antunes, R. (2009). Os sentidos do trabalho. São Paulo, SP: Boitempo.

Araújo, R. R., \& Sachuck, M. I. (2007). Os sentidos do trabalho e suas implicações na formação dos indivíduos inseridos nas organizações contemporâneas. Revista de Gestão, 14(1), 53-66.

Ardichvili, A., \& Kuchinke, K. P. (2009). International perspectives on the Meanings of Work and working: Current research and theory. Advances in Developing Human Resources, 11 (2), 155-167. doi:10.1177/1523422309 333494

Arthur, M. B., \& Rousseau, D. M. (1996). The boundaryless career as a new employment principle. In M. B. Arthur (Org.), The boundaryless career (pp. 3-20). New York, NY: Oxford University Press. 
Bauman, Z. (2000). Modernidade líquida. São Paulo, SP: Zahar.

Bauman, Z. (2004). Identidade. São Paulo, SP: Zahar.

Bendassolli, P. F., \& Borges-Andrade, J. E. (2015). Escala do trabalho com sentido. In K. Puente-Palácios \& A. L. A. Peixoto (Org.), Ferramentas de diagnóstico para organizações e trabalho (pp. 221-231). Porto Alegre, RS: Artmed.

Bertoncelo, V., \& Junqueira, L. (2018). Novas formas de ocupação, do trabalho e condições. Revista Organizações em Contexto, 14(27), 187-210. doi:10.15603/1982-8756/roc.v14n27p187-210

Bianchi, E. M. P. G. (2013, November). Sentido do trabalho: Uma demanda e um desafio contemporâneo. Paper presented at the Fourth Encontro Nacional de Gestão de Pessoas e Relações de Trabalho, Brasília, DF.

Bianchi, E. M. P. G., Quishida, A., \& Foroni, P. G. (2017). Atuação do líder na gestão estratégica de pessoas: Reflexões, lacunas e oportunidades. Revista de Administração Contemporânea, 21 (1), 41-61. doi:10.1590/1982-7849rac 2017150280

Boas, A. A. V., \& Morin, E. (2017). Qualidade de vida no trabalho: Um modelo sistêmico de análise. Revista Administração em Diálogo, 19(2), 62-90. doi:10.20946/rad.v19i2.31720

Borchardt, P., \& Bianco, M. F. (2016). Meanings of volunteer work: A study with members of a Lutheran institution. Revista de Administração Mackenzie, 17(5), 61-84. doi:10.1590/1678-69712016/administracao.v17n5p61-84

Cabral, A. M. S. (2011). Conciliação ou conflito entre o trabalho e as outras esferas da vida social na inserção profissional dos diplomados do ensino superior. International Journal on Working Conditions, (1), 68-77.

Crabtree, S. (2013). Worldwide, $13 \%$ of employees are engaged at work: Low workplace engagement offers opportunities to improve business outcomes. GALLUP. Retrieved from http://news.gallup.com/poll/165269/ worldwide-employees-engaged-work.aspx

Carochinho, J. A. B. (2009). Trabalho e novas formas de organização do trabalho: Para além do Hedonismo e da Eudaimonia (Unpublished doctoral dissertation). Universidade de Santiago de Compostela, Faculdade de Psicoloxia Social, Básica e Metodoloxía, Santiago de Compostela, Galiza.

Chalofsky, N. E. (2010). Meaningful workplaces. San Francisco, CA: JosseyBass.

Cortella, M. S. (2007). Qual é a tua Obra? São Paulo, SP: Vozes. 
Creswell, J, W. (2013). Research design: Qualitative, quantitative, and mixed methods approaches. Lincoln, NE: Sage.

Dejours, C. (2009). A Loucura do trabalho. São Paulo, SP: Cortez.

Dik, B. J., Duffy, R. D., Blake, A. A., O’Donnell, M. O., Shim, Y, \& Steger, M. F. (2014). Purpose and meaning in career development applications. The Counseling Psychologist, 9(29). doi:10.1177/0011000014546872

Dourado, D. P., Holanda, L. A., Silva, M. M. M., \& Bispo, D. A. (2009). Sobre o sentido do trabalho fora do enclave de mercado. Cadernos EBAPE.BR, $7(2), 349-367$.

Fávero, L. P., Belfiore, P., Silva, F. L., \& Chan, B. L. Análise de dados: Modelagem multivariada para tomada de decisões. Rio de Janeiro, RJ: Elsevier.

Fernandes, C. M., Siqueira, M. M. M., \& Vieira, A. M. (2014). Impacto da percepção de suporte organizacional afetivo: $O$ papel moderador da liderança. Revista Pensamento Contemporâneo em Administração, 8(4), 140-162.

Frankl, V. (2008). Em busca de sentido. São Paulo, SP: Vozes.

Gorz, A. (2007). Metamorfoses do trabalho. São Paulo, SP: Annablume.

Hackman, J. R., \& Oldham, G. R. (1976). Work redesign. Reading, MA: Addison-Wesley.

Hall, D. T. (1976). Careers in organizations. Santa Monica, CA: Goodyear.

Hair, J. F., Black, B., Babin, B., Anderson, R. E., \& Tatham, R. L. (2009). Análise multivariada de dados. Porto Alegre, RS: Bookman.

HayGroup (2013). Por que está tão crítico reter profissionais? (Relatório de Pesquisa, 2013, February). Retrieved from: http://www.haygroup.com/ downloads/br/Retencao_funcionarios_Hay_Group.pdf

Heller, F., \& Ruiz-Quintanilla, S. A. (1995). The work ethic (CAHRS Working Paper No. 95-08). Ithaca, NY: Cornell University, School of Industrial and Labor Relations, Center for Advanced Human Resource Studies.

Holbeche, L., \& Springett, N. (2004). In search of meaning in the workplace. London, UK: Roffey Park Institute.

Kuchinke, K. P. (2009). Changing meanings of work in Germany, Korea, and the United States in historical perspectives. Advances in Development Human Resources, 33(2), 168-188. doi:10.1177/1523422309332780

Kuchinke, K. P., Ardichvili, A., Borchert, M., \& Rozanski, A. (2009). The meaning of working among professional employees in Germany, Poland 
and Russia. Journal of European Industrial Training, 33(2), 104-124. doi:10.11 08/03090590910939021

Kuchinke, K. P., Ardichvili, A., Borchert, M., Cornachione, E. B., Cseh, M., Kang. T., . . \& \& Zav'jalova, E. (2011). Working meaning among mid-level professional employees: A study of the importance of work centrality and extrinsic and intrinsic working goals in eight countries. Asia Pacific Journal of Human Resources, 49(3), 264-284. doi:10.1177/1038411111413217

Lemos, A. H. C. (2013). Empregabilidade e individualização da conquista do emprego. In M. Balassiano \& I. S. A. Costa (Org.), Gestão de carreiras (pp. 49-64). São Paulo, SP: Atlas.

Lemos, A. H. C., Cavazotte, F. S. C. N., \& Souza, D. O. S. (2017). De empregado a empresário: Mudanças no sentido do trabalho para empreendedores. Revista Pensamento Contemporâneo em Administração, 11 (5), 103-115.

Malone, T. W. (2004). The future of work: How the new order of business will shape your organization, your management style and your life. Boston, MA: Harvard Business Review.

Markos, S., \& Sridevi, M. S. (2010). Employee engagement: The key to improving performance. International Journal of Business and Management, 5(12), 89-96.

Martin, M. W. (2010). Meaningful work. New York, NY: Oxford University Press.

Martins, G. A. (2006). Estudo de caso. São Paulo, SP: Atlas.

Martins G. A., \& Theóphilo, G. A. (2009). Metodologia da investigação científica para ciências sociais aplicadas. São Paulo, SP: Atlas.

Morin, E. M. (2001). Os sentidos do trabalho. Revista de Administração de Empresas, 41(3), 8-19.

Morin, E. M. (2004, August). The meaning of work in modern times. Paper presented at the $20^{\circ}$ World Congress of Human Resources Management, Rio de Janeiro, RJ.

Morin, E. M., Tonelli, M. J., \& Pliopas, A. L. V. (2007). O trabalho e seus sentidos. Psicologia \& Sociedade, 19(1), 47-56.

Morin, E. M. (2008). The meaning of work, mental health and organizational commitment (IRSST report R-585). Psychological Health Studies and Research Projects. Retrieved from https://www.researchgate.net/publication/ 277313871

Morin, E. M., \& Aubé, C. (2008). Psicologia e gestão. São Paulo, SP: Atlas. 
Oliveira, S. R. de, Piccinini, V. C., Fontoura, D. dos S., \& Schweig, C. (2004, September). Buscando o sentido do trabalho. Paper presented at the $28^{\text {th }}$ national meeting of the Associação Nacional de Pós-Graduação e Pesquisa em Administração, Curitiba, PR.

Pereira, J. C. R. (2004). Análise de dados qualitativos. São Paulo, SP: Edusp.

Pestana, M. H., \& Gageiro, J. N. (2008). Análise de dados para ciências sociais. Lisboa, PT: Síbalo.

Porto, J. B., \& Tamayo, A. (2008). Valores no trabalho. In. M. M. M. Siqueira (Org.), Medidas do comportamento organizacional (pp. 295-307). Porto Alegre, RS: Artmed.

PricewaterhouseCoopers. (2018, March). Megatrends. Retrieved from https://www.pwc.co.uk/issues/megatrends

Rodrigues, A. L., Barrichello, A., Irigaray, H. A. R., Soares, D. R., Morin, E. M. (2017). O trabalho e seus sentidos: um estudo com peritos da Polícia Federal. Revista de Administração Pública, 51 (6), 1058-1064. doi:10.1590/00 34-7612159318

Rohm, R. H. D., \& Lopes, N. F. (2015). O novo sentido do trabalho para o sujeito pós-moderno: Uma abordagem crítica. Cadernos EBAPE.BR, 13(2), 332-345. doi:10.1590/1679-395117179

Rosso, B. D., Dekas, K. H., \& Wrzesniewski A. (2010). On the meaning of work: A theoretical integration and review. Research on Organization Behavior, 30, 91-127. doi:10.1016/j.riob.2010.09.001

Ruiz-Quintanilla, S. A., \& England, G. W. (1994). How working is defined (CAHRS Working Paper Series No. 237). Ithaca, NY: Cornell University, School of Industrial and Labor Relations, Center for Advanced Human Resource Studies.

Ruiz-Quintanilla, S. A., \& Claes, R. (2000). MOW Research Programs. In J. A. Katz (Org.), Databases for the study of entrepreneurship (pp. 335-391) New York, NY: JAI/Elsevier.

Selltiz, C., Wrightsman III, L. S., \& Cook, S. W. (2007). Métodos de pesquisa nas relações sociais (Vol. 1). São Paulo, SP: EPU.

Selltiz, C., Wrightsman III, L. S., \& Cook, S. W. (2010). Métodos de Pesquisa nas Relações Sociais (Vol. 2). São Paulo, SP: EPU.

Society for Human Resource Management. (2012). SHRM's HR Trend Book. HR Magazine, 56(12), 52-99. 
Society for Human Resource Management. (2017). Employee job satisfaction and engagement; the doors of opportunity are open. Retrieved from https:// www.shrm.org/hr-today/trends-and-forecasting/research-and-surveys/ Documents/2017-Employee-Job-Satisfaction-and-Engagement-ExecutiveSummary.pdf

Silva, M. P., \& Simões, J. M. (2015). O estudo do sentido do trabalho: Contribuições e desafios para as organizações contemporâneas. Revista Capital Científico, 13(3), 136-151. doi:10.5935/2177-4153.20150027

Spisak, B. R., O’Brien, M. J., Ncholson, N., \& Van Vugt, M. (2015). Niche construction and the evolution of leadership. Academy of Management Review, 40(2), 291-306. doi:10.5465/amr.2013.0157

Tolfo, S. R. (2015). Significados e sentidos do trabalho. In P. F. Bendassolli \& J. E. Borges-Andrade (Org.), Dicionário de psicologia do trabalho e das organizações (pp. 617-625). São Paulo, SP: Casa do Psicólogo.

Trindade, L. H., Trindade, C. G., \& Nogueira, E. C. O. R. (2015). Lacunas na pesquisa em gestão de pessoas: Uma proposta de agenda para pesquisas futuras. Perspectivas em Gestão \& Conhecimento, 5(1), 169-183.

Ulrich, D., \& Ulrich, W. (2011). Por que trabalhamos? Porto Alegre, RS: Bookman.

Ultra. (2016). Ultra 2016. Retrieved from http://www.ultra.com.br

Vecchio, R. P. (1980). The function and meaning of work and the job: Morse and Weiss (1955) revisited. Academy of Management Journal, 23(2), 361-367.

Yukl, G. (2012). Effective leadership behavior: What we know and what questions need more attention. Academy of Management Perspectives, 26(4), 66-85. doi:10.5465/amp.2012.0088

Wrzesniewski, A. (2003). Finding positive meaning in work. In K. S. Cameron, J. E. Dutton, \& R. E. Quinn (Org.), Positive organizational scholarship (pp. 296-308). San Francisco, CA: Berrett-Koehler Publishers. 


\section{AUTHOR NOTES}

Eliane Maria P. G. Bianchi, Faculdade de Economia, Administração e Contabilidade, Universidade de São Paulo (USP).

Eliane Maria P. G. Bianchi is now Professor of postgraduate degree at Campo Limpo Paulista Centro Universitário Campo Limpo Paulista (Unifaccamp).

Correspondence concerning this article should be addressed to Eliane M. P. G. Bianchi, Rua Guatemala, 167, Jardim América, Campo Limpo Paulista, São Paulo, Brazil, CEP 13231-230.

E-mail: eliane.pires.bianchi@terra.com.br

\section{EDITORIAL BOARD}

Editor-in-chief

Silvio Popadiuk

Associated Editor

Alcides Barrichello

Technical Support

Vitória Batista Santos Silva

\section{EDITORIAL PRODUCTION}

Publishing Coordination

Irina Migliari

Language Editor

Daniel Leão

Editorial Trainee

Maria Luiza Vanz

Layout Designer

Emap

Copy Editor

Irina Migliari

Graphic Designer

Libro 